\title{
Self-medication in times of COVID-19. A perspective from Peru
}

\section{Automedicación en tiempos de COVID-19. Una perspectiva desde Perú}

\author{
J. Shamir Barros-Sevillano, ${ }^{1 *}$ Carmen P. Sandoval, ${ }^{1}$ Lider S. Alcarraz-Mundial ${ }^{1}$ and Joshuan J. Barboza ${ }^{2}$ \\ ${ }^{1}$ Medical School, Faculty of Health Sciences, Universidad César Vallejo, Trujillo; ${ }^{2}$ Medical School, Universidad Señor de Sipán, Chclayo. Peru
}

By September 6, 2020, 676,848 confirmed cases of COVID-19 and 29,554 deaths from this cause were reported in Peru, which are figures that identify the disease as the main public health and economic problem in the country, which is ranked fifth in the number of infected subjects in the world, and first in the number of deaths per million population. ${ }^{1}$

Collective concern has favored self-medication, with a close relationship between misinformation by the media and a desperate promotion of the use of medications without scientific basis. Currently, the Peruvian government, through the Ministry of Health, distributes the "COVID kit" for the treatment of patients with mild disease, which includes ivermectin, hydroxychloroquine, azithromycin and paracetamol. ${ }^{2}$ Moreover, in different regions of Peru, ivermectin is openly manufactured and distributed without health registration for outpatient treatment.

In a total sample of 132 patients hospitalized for COVID-19 in a Peruvian hospital, 36 (33.9\%) had already self-medicated prior to admission. The most common drugs were antibiotics $(28.3 \%)$, such as azithromycin and amoxicillin, followed by ivermectin $(20.7 \%)$ and corticosteroids (17\%), ${ }^{3}$ three drugs with little or no clear scientific evidence that allows claiming that their early use has a positive result on the course of the disease ${ }^{4}$ and whereby, on the contrary, adverse effects are being reported.

Of particular concern is early self-medication with corticosteroids, which are only recommended in hospitalized patients who require oxygen therapy; ${ }^{5}$ preemptive use of corticosteroids or at disease onset could prevent the body from fighting the virus and worsen disease presentation.

Paucity of information and non-compliance with health legislation can continue to encourage this practice. To reduce this tendency, it is urgent to educate the population in order to avoid self-medication and inform about the collateral damages it entails.

\section{References}

1. World Health Organization [Internet]. Switzerland: Panel de la OMS sobre la enfermedad por coronavirus (COVID-19); 2020

2. Decreto de urgencia que dicta medidas extraordinarias para garantizar el acceso a medicamentos y dispositivos médicos para el tratamiento del coronavirus y reforzar la respuesta sanitaria en el marco del estado de emergencia sanitaria por el COVID-19. Diario Oficial Del Bicentenaio El Peruano; 2020, May 20.

3. Zavala-Flores E, Salcedo-Matienzo J. Medicación prehospitalaria en pacientes hospitalizados por COVID-19 en un hospital público de Lima-Perú. Acta Med Peru. 2020;37:393-395.

4. Díaz E, Amézaga Menéndez R, Vidal Cortés $P$, Escapa MG, Suberviola B, Serrano Lázaro A, et al. Tratamiento farmacológico de la COVID-19: revisión narrativa de los Grupos de Trabajo de Enfermedades Infecciosas y Sepsis (GTEIS) y del Grupo de Trabajo de Transfusiones Hemoderivados (GTTH). Med Intensiva. 2020.

5. RECOVERY Collaborative Group, Horby P, Lim WS, Emberson JR, Mafham M, Bell JL, et al. Dexamethasone in hospitalized patients with COVID-19 - preliminary report. N Engl J Med. 2020;NEJMoa2021436.
Correspondence:

*J. Shamir Barros-Sevillano

E-mail: jbarros@ucvirtual.edu.pe
Date of reception: 07-09-2020

Date of acceptance: 15-09-2020

DOI: 10.24875/GMM.M21000526
Gac Med Mex. 2021;157:116-116

Contents available at PubMed

www.gacetamedicademexico.com

0016-3813/@ 2020 Academia Nacional de Medicina de México, A.C.. Published by Permanyer. This is an open access article under the CC BY-NC-ND license (http://creativecommons.org/licenses/by-nc-nd/4.0/). 